\title{
Some Types of Endolithic Limestone Lichens.
}

\author{
BY

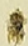 \\ E. J. FRY, M.Sc., \\ Assistant Lecturer in Botany, University College of Wales, Aberystroyth.
}

With Plate XXI and nine Figures in the Text.

\section{INTRODUCTION.}

$\mathrm{A}^{\mathrm{N}}$ investigation of the pioneer cryptogamic vegetation of the CarboniA ferous crystalline limestones of the Great Orme and in S.E. Anglesey was begun in IgI 8 . The present paper deals with the study of several of the more common endolithic lichen thalli found on those outcrops.

Up to the present time little work on embedded lichens has been published, and it was thought that, since new and better methods of sectioning the endolithic thalli had been found, it might be advisable to make a detailed study of certain forms which Bachmann (1) did not describe. It is to Bachmann that we owe our present knowledge of the anatomy of such plants.

\section{General Notes.}

Investigation of the outcrops under discussion shows there is scarcely a square inch not occupied by lichen thalli of some kind, and of these by far the most numerous, both in species and individuals, are the endolithic forms. The majority of these can be detected with the naked eye, since their fruiting organs at maturity appear at the surface, and frequently the endolithic lichens give a tinge of colour to the surface of the rock. The presence of other forms - which fruit but rarely and give very little, if any, colour to the limestone-is betrayed only by the scratching of the rock surface, which gives a bright green or orange 'streak' according to whether the algal constituent of the embedded lichen belongs to the Chlorophyceae or the Trentepohliaceae. In some species, e.g. Verrucaria calciseda, the boundary of the thallus is clearly marked by a black line. In this region the limiting lichen hyphae are dark coloured and in some cases are raised just above the level of the rock.

Over these embedded thalli creep the epilithic forms such as Xanthoria parietina, Lecanora murorum, L. cirrochroum, and species of Physcia, of which only the rhizoids penetrate the limestone already partly broken up by the

[Annals of Butany, Vol. XXXVI. No. CXLIV. October, 1922.] 
action of the endolithic thalli. Apart from such epilithic types there are a few whose thalli are partly epilithic and partly endolithic, e. g. Aspicilia calcarea, the endolithic part only of which has been described by Bachmann (loc. cit.).

\section{Method of Preparation of Material.}

Bachmann prepared and examined slides of the rock with the lichen in situ. To examine the thallus in greater detail he removed the limestone by treating the rock section with hydrochloric acid or Perényi's fluid; but before this could be done all trace of the Canada balsam, used in fixing the rock section to the glass slide for the rubbing-down process in the preparation of rock sections, had to be removed by special methods. It was necessary that this process of decalcification should be carried out on the slide, since the thallus sections were too delicate and of too loose a texture to allow of the usual manipulation. The disadvantages of such a method are obvious. In the first place, rock sections, thin enough to show sufficient detail of the hyphae, cannot be prepared without loss of a certain numberperhaps the majority - of the gonidia, which come out fairly easily in the rubbing-down process. Secondly, in the decalcification of sections, a number of the short portions of hyphae and algae readily break away from such a loose structure, so that a perfect section can rarely be obtained. In the present investigation, rock sections having proved unsatisfactory, the following method was adopted for the preparation of sections of endolithic thalli. From the surface of fairly pure crystalline limestone bearing the endolithic lichens, fragments of about I cm. $-\mathrm{I} \cdot 5 \mathrm{~cm}$. thickness were chiselled. These were then immersed in hydrochloric acid. In order that the effervescence might be very slow the acid was made very dilute. This precaution allowed the true structure to be preserved, which might have been destroyed by too violent a reaction. The process in a number of cases has been observed under the microscope. Effervescence was less rapid from the upper surface. This became woolly in appearance as the limestone was dissolved, and the degree of coarseness of the texture varied with the different lichens. At the end of three or four hours all the calcium carbonate was removed. To the naked eye the thallus, freed of the rock, appeared as a thin rind, from the underside of which spread out a meshwork of very fine, soft hyphal threads, the length, number, and colour of which varied with the different species. When the thallus was touched an impression was given as of a mass of sodden silken threads. This mass collapsed on removal from the liquid. The whole was washed gently in running water for twenty-four hours, then fixed in chrom-acetic, washed, dehydrated, embedded, and serial sections cut in the usual way. It should be mentioned that before washing free of the acid the underside of the material was examined under the microscope for insoluble impurities. These, when present, were removed, care being 
taken not to harm the tissues in any way. If this precaution were not taken the microtome knife would suffer badly and accurate sectioning would be impossible. Although many hundreds of sections have been prepared, remarkably few have been spoilt in this way.

Sections of all thicknesses between $2 \mu$ and $20 \mu$ were examined, but for the purpose of this investigation $8 \mu$ was found to be the most suitable. Vertical sections of numerous thalli were cut, and from some thalli series of tangential sections, each $8 \mu$ thick, were made from the outermost region of the cortex to the innermost limits of the rhizoidal zone.

Heidenhain's haematoxylin was found to be the most convenient staineither used alone or with Congo red as a counter-stain; methylene blue also proved very useful. Although most of the permanent sections have been mounted in Canada balsam, this was not the best medium for the examination of such tissues, since the refractive index of the fungal walls was so near that of the balsam that their boundaries could only be distinguished with difficulty. Some of the clearest preparations have been made by mounting the stained sections in colourless glycerine jelly.

By teasing out freshly decalcified material it was possible to study the rhizoidal zone, but, owing to the crowding of the surface layers by thalli which only occupy small areas, one could not always be certain to which thallus the rhizoids under examination belonged, and it was impossible to cut sections of material in the freshly decalcified state. There was a further disadvantage in using unsectioned material. The hyphae low down in the rock did not always belong to the plant occupying the surface at the time, for though the previous inhabitant of the surface layers might have been removed by weathering action, or by the more rapid growth of another lichen, its rhizoids remained for some time deep in the rock and apparently healthy.

\section{Classification of Endolithic Lichens.}

A simple classification based on the structure of the thallus is the one adopted in this discussion. Although the fruiting organs are not taken into consideration in this classification, yet they are described, since they offer certain points of interest in connexion with the endolithic habit.

I. Wholly endolithic

II. Partly endolithic.

\section{A. Heteromerous. (Algal cells-Chlorophyceae.) \\ B. Homoiomerous. \\ (Algal cells-Trentepohliaceae or Cyanophyceae).}

\section{A. Heteromerous. (Algal cells-Chlorophyceae).}

(a) Cortical zone-loose.

(b) " " fairly compact. (c) " " discontinuous.

(a) No zonation (only Trentepohlia form described).

Two parts to thallus:

(a) Epilithic part-Cortex, gonidial layer, and medulla, but no rhizoids.

(b) Endolithic part-Accessory gonidial groups plus rhizoidal zone. 


\section{Wholly Endolithic Types. A. \\ a. Verrucaria calciseda, D. C.}

Under the microscope the surface of the limestone immediately above Verrucaria calciseda appears white and rather granular, exhibiting very numerous black spots and empty pits. The spots are of two kinds. The larger circular patches are the carbonaceous lids of the perithecia, while the smaller dots are the dark external ends of hyphae of the cortical zone, or, as is often the case in these endolithic forms, they are small colonies of minute blue-green algae, which adhere to the surface. The pits are the positions of the old perithecia.

After decalcification the thallus is very thin, soft, and delicate, the upper surface having a fine woolly appearance. Both the upper and lower surfaces are white, as are also the short rhizoids. In a vertical section (Pl. XXI, Fig. 1) can be seen the three zones: cortical, gonidial, and rhizoidal. From the cortex to the limits of the rhizoids measures $670 \mu$. The whole thallus, except for the short dark hyphal tips, is embedded within the rock.

Cortical zone. The cortex has an average thickness of $28 \mu$. Although it appears fairly continuous the hyphae are not evenly distributed. In certain regions, i. e. just above the main groups of gonidia, the hyphae are shorter and more closely packed, forming a dense tissue. Linking up these clumps one with another are many branching hyphae which are composed of the short cells or more elongated ones. Towards the surface of the rock the cortical hyphae tend to be of a greyish brown colour. Those that are actually at the surface are a deep brown or black (Pl. XXI, Fig. I, a).

Gonidial zone. The average width of the gonidial zone is about $75 \mu$. In a longitudinal section the bright green gonidia are arranged in more or less regular, elongated groups. These branch in one or more directions. The long axis of the gonidial group usually is at right angles to the surface of the rock, though frequently it may run almost parallel with it (Pl. XXI, Fig. 1). The gonidia are wound round by innumerable hyphal threads (Text-fig. I), which, besides enclosing the whole group in a kind of envelope, push their way between the individual gonidia. These hyphae are continuous with the hyphal tissue immediately above the group. The gonidial groups with their hyphal caps are situated in hollows in the limestone, and it is from these that the gonidia are so easily lost in the rubbing process in the preparation of the rock sections by Bachmann's method. From the common envelope of short hyphae with dense contents there are given off numerous branches which connect up the neighbouring groups of algal cells (Text-fig. I). Other branches pass in a downward direction, branch freely, and anastomose while still in the region of the gonidial zone.

Rhizoidal zone. The hyphae which are deepest in the rock are narrower 
and less regular in shape than those nearer the surface. The contents of a cell in the lower rhizoid region are small in comparison with those or a hypha of the gonidial zone, but the nucleus is very plainly marked. In the upper rhizoidal zone the hyphae resemble very closely those in the neighbourhood of the gonidial groups. Commonly the terminal cell or cells of a branch or filament swell up into a spherical body or bodies which often reach a diameter of $\mathrm{I} 4 \mu$ or more (Text-fig. 2). These are usually thin walled, but frequently become thicker and dark coloured; particularly in the marginal regions of Verrucaria calciseda. These spherical or inflated hyphae are full of a highly refractive greenish oil. Neither the function nor the formation of this substance is properly understood, but various suggestions

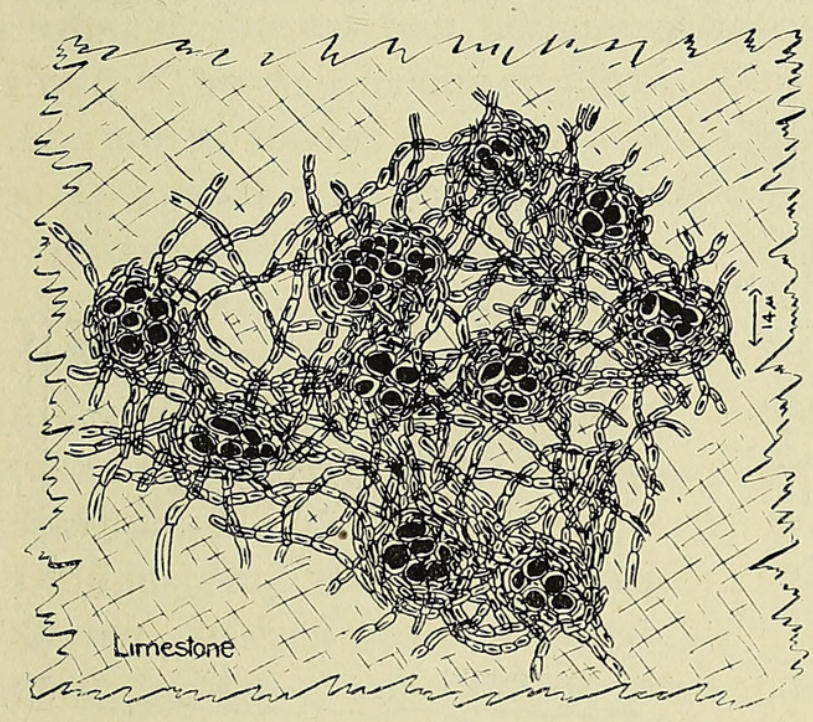

TeXT-FIG. I. Verrucaria calciseda (tangential section $30 \mu$ in limestone), showing gonidial groups encircled by hyphae, and hyphae crossing from group to group.

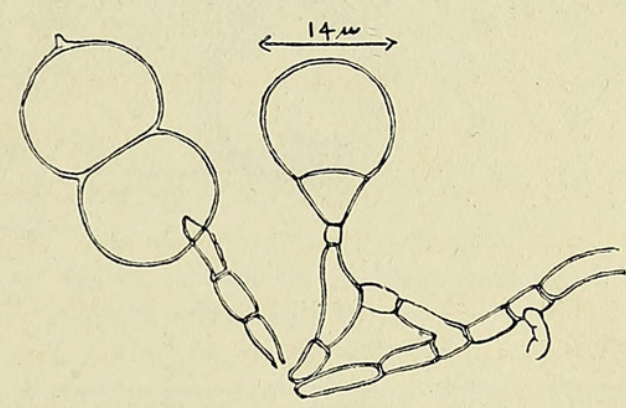

TEXT-FIG. 2. Verrucaria calciseda. Simple inflations of hyphae.

have been made which will be referred to in the general discussion. From numerous cases examined in other forms it seems that the oil accumulates and the wall enlarges or stretches to keep pace with the accumulation. The inflated hyphae which are present immediately below the gonidial zone are found commonly all through the rhizoidal region. It has been mentioned that at the margin of the thallus there is a black line. In longitudinal section this shows as a mass of dark-coloured, slightly enlarged hyphal cells, just above the level of the limestone. Immediately below this in the rock the decomposing remains of the neighbouring thallus are seen in the meshes of the dark marginal hyphae (Pl. XXI, Fig. 2). The presence of this dark mass at the surface is not constant. In other places the hyphae do not come above the level of the rock, but remain more loosely packed in the limestone. They are dark coloured, thick walled, and bear numerous terminal inflations. Often they are found in the rock ahead of 
the thallus on the surface, penetrating the cortical gonidial and rhizoidal regions of the neighbouring lichen.

The perithecium. The whole perithecium, except for the lid or cap, is embedded in a deep pit in the rock. This pit usually reaches down to two and a half to three times the depth of the gonidial zone (Pl. XXI, Fig. I, and Text-fig. 3). The fruiting body figured in the plate is not mature; asci are present, but ascospores have not yet been formed. Paraphyses, as is usual in this species, have decomposed and formed mucilage, which is indicated near the base of the neck. Lining the neck are numerous periphyses. The lid already shows the position of the pore. Even at immature stages the fruiting body never completely fills the hollow. The origin of the perithecium is within the limestone, and at an early stage the

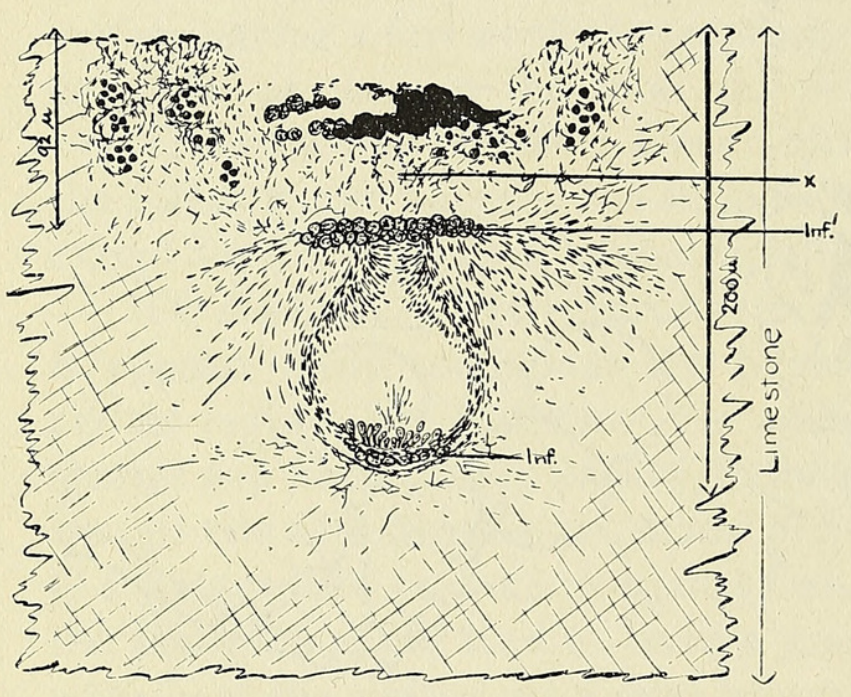

TeXT-FIG. 3. Vermcaria calciseda. Young apothecium (longitudinal section). Inf. = inflated hyphae; Inf'. = inflated hyphae forming lid ; $x=$ disorganizing part of thallus and dissolving limestone in process of dissolution.

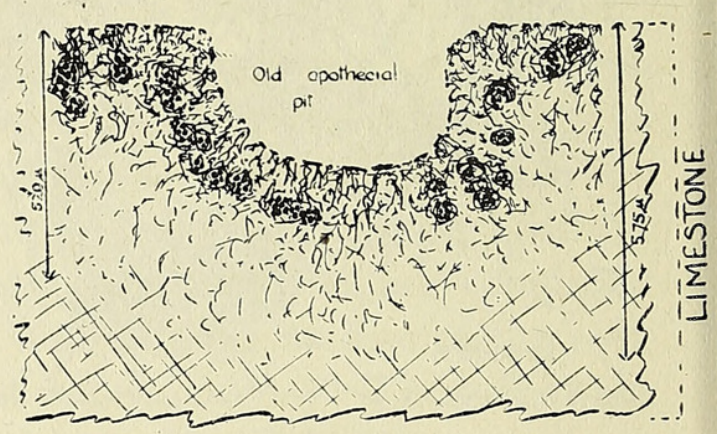

TEXT-FI'G. 4. Lecidea immersa. Old apothecial pit being recolonized by gonidia and hyphae.

black lid is found to be situated immediately over the developing perithecium, but completely inside the thallus (Text-fig. 3). In the earliest stages this lid is seen to be made up of thin-walled, inflated cells which at a later period turn black and become thick walled, and can scarcely be distinguished (Pl. XXI, Fig. I). As the neck and perithecium develop, so the lid is pushed up through the limestone and the tissue above becomes disorganized, ultimately breaking away from the thallus (Plate XXI, Fig. I $b$ ). At the base of the developing perithecium there is a plate of inflated hyphae, which also becomes thick walled and dark coloured later on (Text-fig. 3 and Pl. XXI, Fig. 1). After the spores have been freed through the pore the wall shrinks and the old perithecium is washed or is blown out of the depression. This pit is not filled in with hyphae, as are cavities similarly left in aerial lichens, but the limestone lining the hollow is soon occupied by gonidial groups (Text-fig. 4). 


\section{A. a. Lecidea immersa, Ach.}

The external appearance of Lecidea immersa is not unlike that of $V$. calciseda. There is the white or pale grey, granular surface, but except for the marginal regions fewer black dots, representing the external hyphal ends, are present. The black or dark-brown fruiting bodies appear larger than those of $V$. calcised $a$, and although the general shape of the apothecial area is circular, yet not uncommonly one finds them with an oval outline-probably this is the result of fusion of two apothecia developing closely together. After treatment with hydrochloric acid, the thallus of Lecidea is still very like Verrucaria, although it is thinner and only penetrates the limestone to a depth of $400 \mu$. The vertical section also shows certain similarities, and because of this a detailed description will not be given. The main points of difference are as follows: The cortex is $34 \mu$ wide, and between the hyphal groups-even at the margin where the tissue is denser-there are fewer hyphae passing from group to gronp. Near the margin there are many hyphae with brown external tips.

The gonidial zone is wider, varying between $80 \mu$ and $100 \mu$, but this is due to the fact that the

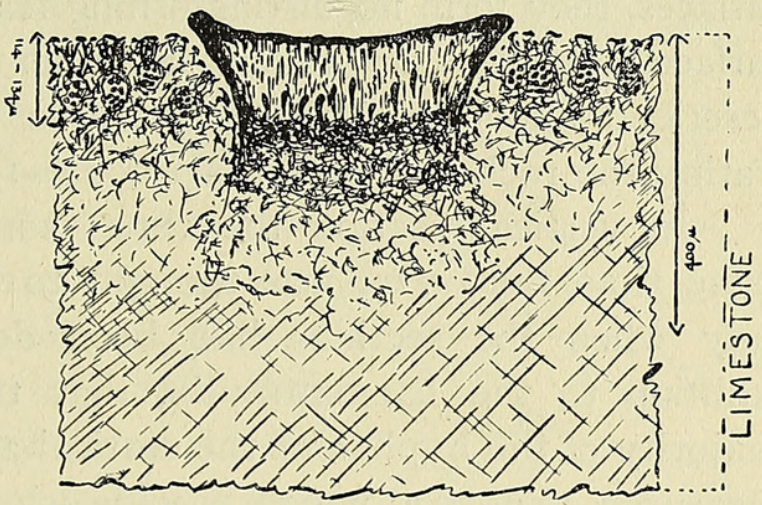

TeXT-FIG. 5. Lecidea inmersa. Young apothecium (longitudinal section). clumps are somewhat scattered in the vertical direction. Apart from this the two gonidial zones are rather alike, except that, as in the cortex, there are fewer hyphae crossing from group to group.

The rhizoidal zone offers the most striking difference between the two species. In L. immersa there are no inflated hyphae in the thallus. Cells of about twice the width of the ordinary hyphae are present, but even these are very few. The hyphae of the rhizoidal region of Lecidea are very much narrower than those of Verrucaria; also, the width of the rhizoidal zone as a whole is considerably less in the former type.

The apothecium. Although from the surface the young state of the fruiting body appears very like the perithecium of Verrucaria, its construction is very different. This is clearly seen in the longitudinal section (Text-fig. 5). It is of the ordinary lecideine type and needs no description. The pit which has been formed during the development of the apothecium reaches down to about $200 \mu$ or more. In the tissue of the hypothecium there are many small crystals which have not been dissolved by the acid. Although inflated hyphae are not found in longitudinal section either in the young apothecium or in the thallus tissue, yet in freshly decalcified material mature 
apothecia were found to possess numerous spherical oil cells, which usually occurred singly. These were readily seen when mature apothecia were crushed by slight pressure of the cover-slip. They occurred in the dense tissue of the hypothecium and in the region immediately below. As in Verrucaria, once the fruiting body has been removed, the walls of the pit are occupied afresh by gonidia and hyphae. Spermogonia are also found in small hollows, but these penetrate only to the base of the gonidial zone.

\section{A.b. Lichen ' $X$ ' (not determinable).}

The surface of the thallus ' $X$ ' in the limestone shows nothing distinctive. There are no apothecia or perithecia and no black spots representing the external tips of hyphae. Very occasionally one finds the small blue-green algal colonies, but, as they are commonly found on endolithic lichen surfaces, they form no distinguishing feature. Whèn decalcified the thallus surface appears very much smoother than that of either of the types described above, and there is also a greater thickness, the lichen penetrating the rock to a depth of $\mathrm{I}, 000 \mu-\mathrm{I}, \mathrm{I} 00 \mu$.

In vertical section the three zones are clearly distinguished. For some time the cortex was thought to be of a very loose texture. It was only when the sections had been deeply stained with Congo red, in addition to the haematoxylin, that the very fine delicate walls of the majority of the hyphae of the cortical zone could be detected. The cortex measures $46 \mu-70 \mu$, which is wide when compared with Lecidea immersa and $V$. calciseda. It seems to be composed of two kinds of hyphal filaments : (i) the smaller number, made up of wide quadrate cells possessing dense contents which stain deeply with haematoxylin; (ii) the larger number, whose contents do not stain, the presence of these only being betrayed by the faint pinkish tinge of their walls (Pl. XXI, Fig. 3). The hyphae with the dense contents can be traced very easily from the outer edge of the thallus to the gonidial zone. In this region they appear to pursue a slightly tortuous path, branch but little, and generally preserve a direction at right angles to the surface of the rock. Usually the end one or two cells are colourless and correspond to the second type of hyphae. Filling in nearly all the spaces not occupied by the above hyphae are those filaments the cells of which appear to be without contents. At the outer limit of the thallus, together with the end cells of the former type, they seem to form a fairly continuous layer, which may be slightly brownish on the extreme outside.

The gonidial zone measures on the average $92 \mu-140 \mu$. This great width is due to the fact that the narrow gonidial groups are rather elongated in the vertical direction. The size of the groups varies considerably (compare Text-figs. 7 and 8 with Pl. XXI, Fig. 3). The gonidia, both as clusters and individuals, are spun round by both kinds of hyphae, but more 
particularly by those with dense contents. Those in the gonidial region are much narrower than similar hyphae in the cortex. From each of the little clusters filaments branch off and cross over or pass down to the neighbouring groups when the latter are situated some distance apart. When the clusters are close together these hyphae pass downwards, forming a dense strand of parallel filaments.

Rhizoidal zone. From the gonidial zone hyphae of both kinds pass downwards, branch very freely, and appear to form a dense network. In this region of transition from the upper zone to the rhizoidal region nearly all the hyphae appear to have the power of producing small inflated cells. These may be formed in continuous rows, or with short lengths of narrow hyphae in between. They resemble very closely the 'empty' cells of the cortical and gonidial zones. Fro this mass of hyphae spring the 'rhizoids'. These are narrow filaments, except when inflated to $14 \mu$ or thereabouts, with cross-walls far apart. They contain small globules of oil which is of the same nature as that found in the spherical dilations. Instead of the swellings occurring singly at the end of filaments as in $V$. calciseda, they are seen in ' $\mathrm{X}$ ' to be most frequently in simple chains (Text-fig. 6) and sometimes in very small clusters. Frequently in a longitudinal section one can see that the structure of the rock has some influence on the rhizoids. The parallel lines of cleavage of large calcite crystals are often followed by branches of smaller inflated hyphae which join on to the main filament at an angle of $60^{\circ}$.

Reproductive organs. Ascus-bearing bodies and asci have not been found in lichen ' $X$ ', but there are two kinds of spore-bearing organs apart from

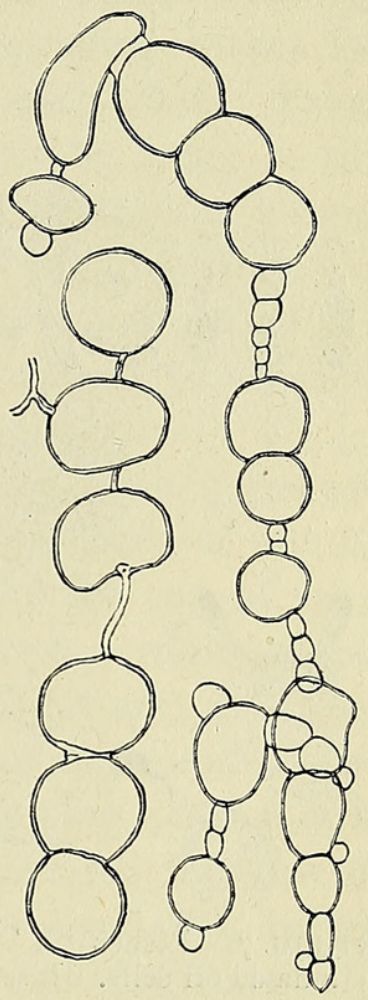

TEXT-FIG. 6. Lichen ' $X$ '. Inflated hyphae. these. Both form pits which penetrate the limestone to more than twice the depth of the gonidial zone.

Spermogonia. The first kind one recognizes as simple immersed spermogonia (Text-fig. 7) bearing on their infolded walls countless spermatia of the club-shaped type. Numbers of these spermogonia have been cut both horizontally and longitudinally. At the apex the neck is narrow and generally circular in cross-section and measures about $70 \mu$ in diameter; if oval in outline the measurements are about $55 \mu \times 180 \mu$. Lower down in the rock where the spermogonium reaches its greatest breadth the average measurement is $200 \mu$.

The second spore-bearing bodies appear very like pycnidia, but they bear macrospores. In general appearance they resemble the spermogonia, but 
they are without the dense lining of very small hyphae. The spores, however, are very different from spermatia (Plate XXI, Figs. 4, 5, 6, and 7 , and Text-fig. 8). They are borne on the hyphae lining the cavities and generally occur in such masses that it is difficult to see their actual origin. Since the spores are so large, $5 \mu$ or more, the size of the cavity itself is very much reduced. They (Plate XXI, Figs. 4, 5, 6, and 7) are at first colourless and apparently thin walled, but later become thick walled and dark brown. In the younger stages one is able to see large projections into the cell cavity (Plate XXI, Figs. 6 and 7). Apart from such projections as appear almost

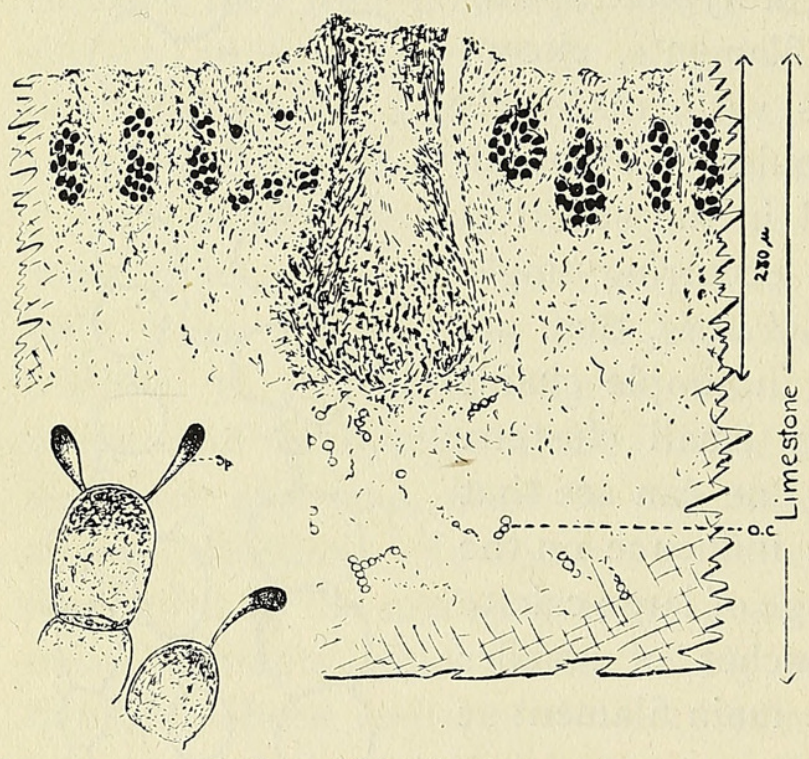

TEXT-FIG. 7. Lichen ' $\mathrm{X}$ '. Spermogonium; o.c. = inflated oil cells. Inset : $S p$. $=$ spermatium.

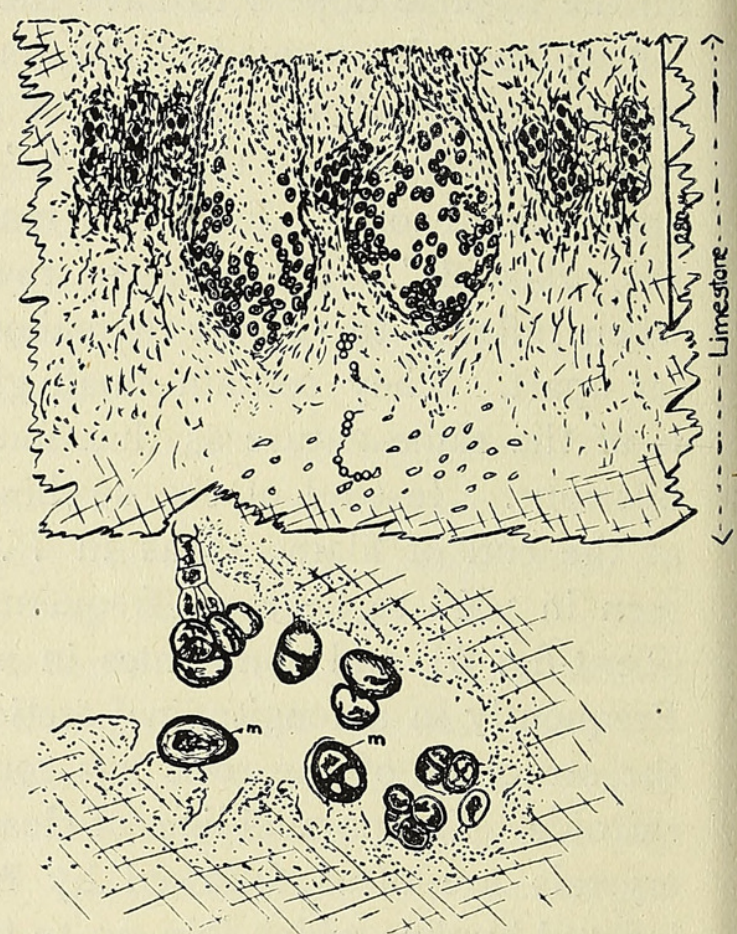

TeXt-FIG. 8. Lichen' $\mathrm{X}$ '. Pycnidia with macrospore. Inset: portion of wall bearing macrospores. $m=$ macrospore.

to divide a cell into two, the spores may be uniseptate (Plate XXI, Figs. 6 and 7), though often they are simple (Plate XXI, Fig. 4) and without projections into the cavities.

Tulasne (7) has recorded the presence of both spermogonia and pycnidia on the lichen thallus. The pycnidiospores or stylospores were described as ' larger bodies than spermatia, occasionally septate, and containing oil drops or guttulae. These spores are pyriform or ovoid in shape and are always borne at the tips of simple sporophores' (8). In the case of lichen ' $\mathrm{X}$ ', also, the two kinds of spores are quite distinct.

\section{A.c. Placodium rupestre, var. calvum, forma incrustans, A. L. S.}

Thalli of Placodium rupestre, var. calvum, forma incrustans, are small, being about one square centimetre in area. Nevertheless, they are often 
crowded with small yellow immersed apothecia. To the naked eye the thallus appears white, but under the microscope the surface is seen to be speckled with black or dark-brown spots and patches. It is granular and more irregular than in the three types previously described. After scratching away the superficial layers of limestone, comparatively large, bright green nests of gonidia are exposed. The apothecium originates within the rock, as in Lecidea immersa and $V$. calciseda-the limestone above gradually breaking down, caving in, and falling on the top of the young apothecium. This accounts for many of the hollows appearing too big for the young apothecia.

After decalcification the upper surface of the thallus appears coarsely woolly, the comparatively large white clumps of tissue being rather far apart and apparently having little or no connexion with each other. From the underside as well as from the upper, the apothecia can be seen; in the former case they appear as hemispherical, pale yellowish, protruding lumps. The thallus is very thin, the average thickness being $160 \mu$, and there are only a very few extremely short rhizoids. The small black spots on the surface have no special significance. Occasionally a brownish patch caps one of the white clumps of tissue, but this feature is not common.

In vertical section several striking differences from the former types are seen. The thallus, as indicated above, is made up of a number of almost isolated masses of tissue (Plate XXI, Figs. 8 and 9). At the top of each mass, which is situated in a pocket in the limestone, there is a more or less solid layer, about $23 \mu$ thick, of quadrate hyphal cells. This acts as a plug protecting the tissue below, which is composed of hyphae and gonidia-the latter being scattered about without any definite grouping of the cells (Plate XXI, Fig. 9). The algal cells are unusually large for the size of the thallus. From below arise a few hyphae which, for want of a better term, may be called rhizoids, and in these there are no inflated cells. In a typical case (Plate XXI, Fig. 9) from the outside of the 'cap' to the base of the pocket measures $100 \mu$, and including the rhizoids $I 25 \mu$ may be reached. The whole mass is usually narrower towards the outside of the limestone, being only $46 \mu$ in diameter, while at the base it widens or branches and may have a breadth of $92 \mu$ or more. Very few hyphae link up these gonidial groups, so that nowhere does one find either a continuous cortical; gonidial, or rhizoidal zone.

The apothecia usually penetrate the limestone to a depth below the base of the gonidial pockets. They seem to have no more connexion with their thallus than have the parts of the thallus one with another.

From the above description it is seen that $P$. mupestre, var. calvum, forma incrustans, almost merits a position in the B (homoiomerous) section. Against this position there are, however, the caps of hyphal cells above the gonidia which correspond to the cortical tissue in the other endolithic lichen 
thalli-particularly those of section $\alpha$ in $A$-and there is, in addition, the very poorly developed rhizoidal system.

\section{B. a. Lichen ' $Y$ ' (an indeterminate form, since no fruiting bodies have been found).}

A detailed description of this species will not be given, since Bachmann (loc. cit.) has already described a similar form, but as he did not include any detailed drawing of a decalcified section of the thallus as a whole, the present writer ventures to insert this form as illustrating a homoiomerous thallus, and also because in this type there are several points of interest apart from the actual structure of the thallus.

While still embedded in the rock, lichen ' $\mathrm{Y}$ ' has a dark rusty grey colour with numerous black spots, but after decalcification it appears golden brown. The thallus is very thin, measuring only $140 \mu-200 \mu$. No rhizoids are present. In vertical section (Plate XXI, Fig. IO) there is a discontinuous band of dark-coloured hyphae $=\mathrm{X}$, dead Trentepohlia cells $=\mathrm{Y}$, and many dark bodies $=Z$, which appear very like fungal spores. These 'spores' lie on the surface of the thallus and send down into the rock hyphae which wind round the gonidial constituent of the lichen. In fact many cases of this kind have been seen and many of the hyphae of the thallus originate in this way. (Plate XXI, Fig. I3, shows a 'spore' at the surface giving rise to hyphae which encircle the Trentepohlia cell already in the rock; the dotted region represents the limestone.) Dark hyphal cells which lie on the surface put out branches into the rock; these branches are also thick walled and dark coloured, but, where in contact with the gonidial cells, their walls are always colourless and thin. Below the main masses of dark-coloured hyphae and algal cells one usually finds many filaments of Trentepohlia, encircled by hyphae, penetrating the rock. Lower in the limestone the gonidia with their attendant hyphae are less common; and at about $200 \mu$ below the surface they are absent. Sometimes many Trentepohlia filaments lie parallel with each other, particularly near the surface of the limestone, yet the structure of the rock seems to play no part in the structure of the thallus, for the gonidial filaments and the hyphae, when the latter occur alone, lie in the limestone at all angles with the surface.

Generally it is the Trentepohlia which penetrates farthest into the rock, either alone or partly surrounded by hyphae; even in the latter case that part of the algal cell farthest in the rock is usually free of hyphae (P1. XXI, Figs. I I and I2). Since hyphal filaments are found in the rock without gonidia, one must conclude that they too are capable of the pioneer boring of the limestone. This is also clearly indicated by the penetration of the rock by the germinating filaments of the 'spores' at the surface. 


\section{A. Aspicilia calcarea, Koerb. (Lecanora calcarea, Sommerf.).}

Bachmann (loc. cit.) has described Aspicilia calcarea, but only the endolithic part of the thallus. By his method of preparation of sections of endolithic lichens it is impossible to obtain the whole depth of the thallus in one section, but by the method adopted in this investigation it is a very simple matter to section the endolithic and epilithic parts of the thallus in their relative positions. Because such a section has not previously been prepared, it was thought to be advisable to add a few remarks on this type. Fragments of limestone of about $\mathrm{I} \mathrm{cm}$. in thickness, and having on their surface the crustaceous or epilithic part of $A$. calcarea, were chiselled from the surface of the rock, immersed in dilute hydrochloric acid, and the whole process then carried on exactly as before. Since this species grows fairly rapidly over the substratum, care must be taken not to confuse disorganizing endolithic thalli, when they are present, with the endolithic part of Aspicilia. In a longitudinal section of a fully developed thallus the epilithic part is seen to vary in thickness from $190 \mu$ to $250 \mu$, and to consist of cortical, gonidial, and medullary zones of a normal type (Pl. XXI, Fig. I4). The endolithic part is composed of gonidial groups and rhizoids, the latter apparently consisting of two kinds-thin and thick. The 'transition' zone (Pl. XXI, Figs. I4 and I5) of the upper to the lower part is represented by a dense mass of hyphal cells which are slightly enlarged and whose contents are very small and pressed closely against the walls. (Pl. XXI, Fig. I5). In the part of the crustaceous thallus immediately above these cells and directly connected with them are roundish hyphae, some of which appear empty while others have contents of the usual type, i.e. not pressed against the cell-wall. From this zone of slightly enlarged, freely branching hyphae arise (i) the rhizoids, (ii) the hyphae which encircle some of the endolithic gonidial clusters, and (iii) the hyphae which form the large clusters of swollen spherical cells in the upper layers of the rock (Pl. XXI, Fig. I4, and Text-fig. 9). The fine colourless rhizoids are about $2 \mu$ wide and arise from the ends of such filaments as are represented in Pl. XXI, Fig. I5, ph. As Bachmann (loc. cit.) has stated, they are far more numerous than the wider yellowish ones, which are about $5 \mu$ in diameter. The former branch freely and twist about in the substratum, so that in a longitudinal section only short portions of them are seen. They contain oil globules and form small clusters of inflated cells of about $6 \mu$ diameter, which may be found alone or in connexion with the gonidial groups. Lower down in the limestone these narrow hyphae show a tendency to associate in strands, and remind one very strongly of the strands of 'oil hyphae' figured by Lang (loc. cit.) for Biatorella simplex. In longitudinal sections simple chains of inflated hyphae have not been discovered, but 
these have been found in the freshly decalcified material without sectioning. They measured at least $12 \mu$ in diameter and arose from hyphae similar in every respect to the ordinary Aspicilia calcarea type. The simple chain of inflations resembled very closely those described for lichen ' $\mathrm{X}$ ', and since they have not been seen in sections of Aspicilia one feels very doubtful whether they belong to that form.

The wider rhizoids are unevenly distributed and their origin from the hyphae of the crustaceous part of the thallus seems a little obscure. This, together with the fact that they are usually brownish or yellow, makes one doubt their relation to $A$. calcarea, although they are present in most of the sections of $A$. calcarea in the limestone immediately below the epilithic thallus. Bachmann's description of the yellow hyphae found by him below the thallus of this species agrees with those of the present investigation.

The rhizoids penetrate the limestone to a depth of $2,800 \mu$, making the width of the whole thallus over $3,000 \mu$.

Occasionally algal cells are found in the 'transition' zone, but apart from these and the gonidial region of the epilithic thallus, there is the extraordinary development of gonidial groups in the limestone, where they may penetrate to a depth of $280 \mu(\mathrm{Pl}$. XXI, Fig. I 4). If they occur near the surface of the limestone, they are spun round by hyphae which are directly connected with the 'transition' zone: if lower down in the rock, they are encircled by thin-walled rhizoids. In some cases cells with dense contents surround the gonidia; in other cases slightly inflated hyphae with little or no deeply staining contents (Pl. XXI, Fig. I6), and sometimes a mixture of the three, may take part in encircling the algal cells (Pl. XXI, Fig. 17). Generally these groups occur as isolated rounded masses in the rock, and in this respect remind one of the Placodium type of endolithic thallus described. Occasionally these groups are connected vertically with each other (Pl. XXI, Fig. 14), but very rarely is there any lateral communication between them.

Yet another peculiarity obtains in the upper limestone layers below the crustaceous part of $A$. calcarea thallus. Certain thin rhizoidal hyphae, arising in the 'transition' zone in the usual way, penetrate the limestone and immediately branch very freely and form numerous inflated cells in the same way as that indicated for the hyphae of the 'transition' zone in Pl. XXI, Fig. 15. This branching of the hyphae and swelling of the cells goes on until huge clusters of spherical hyphae are formed. Bachmann (loc. cit.) has described the formation of these masses as follows: 'On one of the hyphae there arise, close together, numerous short branches. These go on growing parallel to each other and at right angles to the main hypha, projecting from it in all directions. A dilation of each of the cells of the entire branching system, not excluding those of the main hypha, goes on at the same time, until the spherical shape is attained. As a result of these 
processes the spherules are brought into immediate contact with each other, the whole mass constituting a complex of cells having the appearance of a bunch of grapes in which it is no longer possible to distinguish the cells of the principal hypha from those of the lateral branches.' As Bachmann (loc. cit.) states, they are most frequently found in the uppermost layers of limestone (Pl. XXI, Fig. I4), but since he had not the epilithic part of the thallus in situ he was not able to see the relative position of the largest and more frequent clusters. In the present investigation by far the largest and most conspicuous masses of inflated hyphae are found in the limestone beneath or in the immediate neighbourhood of the apothecia

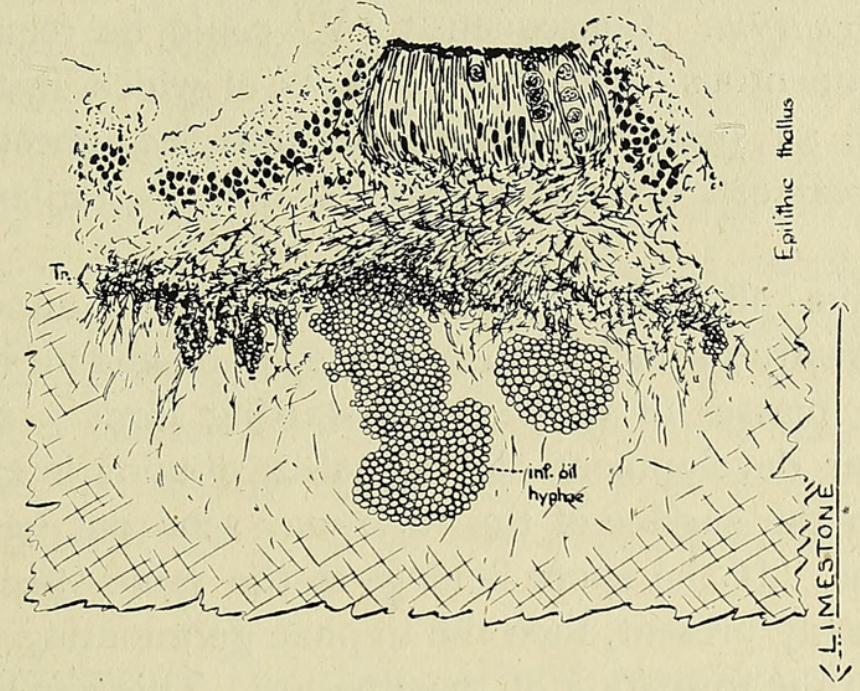

TEXT-FIG. 9. Aspicilic calcarea, showing apothecium and large clusters of inflated cells. $T r$. $=$ 'transition' zone ; inf. oil hyphae $=$ complex mass of inflated oil hyphae.

which occurs in the epilithic part of the thallus (Text-fig. 9). In such clusters the spherical hyphae have a diameter of not more than 6 or $; \mu$. It should be mentioned, both as regards the masses of spherically inflated cells and the endolithic gonidial groups, that they are not equally abundant in all parts of the thallus; in fact, in many parts they may be completely absent.

\section{General Discussion.}

One of the most striking facts about the endolithic lichens here described is that, although they are embedded in the rock, their thalli have a structure similar to that of the sub-aerial forms to which they are related. For example, the genus Lecidea includes both sub-aerial and endolithic species, and both exhibit the heteromerous structure. In both types growth in area goes on at the circumference, where the thalli are thin and consist of fungoid elements alone. Towards the centre, where they are fully developed, the thalli present the typical heteromerous structure. The 
limestone does not seem to hinder in any way the general arrangement and growth of the endolithic lichens. In epilithic thalli it is difficult to find a parallel to that presented by Placodium rupestre, var. calvum, forma incrustans, unless one could compare with it the small isolated squamules of the primary thallus of a Cladonia. The structure of certain species of epilithic and endolithic lichens, which have the filamentous Trentepohlia as their algal constituent, may also be compared. For example, Coenogonium ebenerim has a black-coloured, filamentous epilithic thallus, the hyphae encircling the erect Trentepohlia filaments. In the endolithic form termed ' $Y$ ', the algal filaments penetrate the rock, where they are subsequently surrounded by fungal hyphae in a manner exactly similar to that which obtains in Coenogonium. Consequently ' $\mathrm{Y}$ ' could be regarded almost as an endolithic filamentous form, the filaments of which, instead of growing upwards into the air, penetrate downwards into the limestone, growing in length by an apical cell (Pl. XXI, Figs. I I and I2) similar to that of the aerial form.

The collective mass of gonidia and hyphae in an ordinary lichen thallus is not usually formed from a single spore and a single algal cell, but from several masses of tissue, each starting from a separate growth centre. A similar development of the thallus obtains in endolithic forms. Spores falling on the surface of the rock may send out germinating tubes into the limestone. If the spore belongs to the same species as the endolithic thallus already present, then the hyphae germinating from the former will contribute to the formation of that thallus. This has been observed in several cases in lichen ' $\mathrm{Y}$ ' (Pl. XXI, Figs. IO and 13). In one or two old perithecial pits of Lecidea immersa, where re-colonization of the limestone lining was going on, dark-coloured rounded spores have been observed germinating and sending their hyphae into the cortical tissues of Lecidea. Though these hyphae resembled very closely those forming the cortex, yet the spores were not those of Lecidea immersa, which are oval in shape and colourless. The fate of such foreign hyphae in a thallus is not known, but the idea suggests itself that they may be the starting-point of a more vigorous species which will oust the slower-growing Lecidea. Foreign spores are often found on the surface of the endolithic thalli, where, as a rule, they do not germinate, but merely contribute to the speckled appearance of the surface.

Observations on the infection of the marginal regions by gonidia belonging to the Chlorophyceae have not been made. Since the gonidia are present in little clusters in pockets in the rock, the usual method of spreading the gonidia in the lateral direction, in which the hyphae first separate and then push the algal cells apart, would scarcely seem to hold.

The endolithic lichens undoubtedly obtain protection both from excessive drought and extremes of temperature; yet, from the fact that 
the thalli exhibit the structure of ordinary epilithic forms while embedded in the rock, it may be assumed that the ordinary life of the organisms is carried on unhindered by the enclosing limestone. From the nature of the habitat it would seem that neither the cortex nor the rhizoidal zone is essential for the performance of the simple and obvious functions of protecting the gonidial layer and of fixing the plant to the substratum. In view of this, one may be permitted to conclude that both in epilithic and endolithic forms, unless it is a matter of inherent tendency on the part of the lichen to produce them, both cortical and rhizoidal zones have definite functions to perform, apart from the simpler ones mentioned above.

A feature which is present in most, but not all, endolithic lichens is the development, more particularly in the rhizoidal region, of spherical oil cells. Oil globules, however, are found in the rhizoids of all the endolithic species examined, whether they possess the inflated cells or not. The oil cells occur singly or in pairs, as in the terminal inflations of $V$. calciseda, in simple chains, as in lichen ' $\mathrm{X}$ ', or in large complex cell-masses such as are found in the immersed part of $A$. calcarea. Similar oil hyphae have been found by Rosendahl (9) and Bachmann (10 and 14) in a few lichens which do not grow on a calcareous substratum, but these may be regarded as exceptional cases. It may be helpful at this point to summarize the cases where these inflated cells occur in the thalli described, and also their relative abundance.

Verrucaria calciseda. The rhizoidal and marginal regions, where they are very common. The young perithecium (lid and basal part).

Lecidea immersa. A Apothecial tissue-common.

Lichen ' $\mathrm{X}$ '. Rhizoidal region-common.

Aspicilia calcarea. Rhizoidal region, more particularly in the neighbourhood of the apothecia.

Placodium rupestre, var. calvum, f. incrustans. Absent.

Lichen ' $Y$ '. Absent.

Since they are not present in all forms and in all parts of the thallus they cannot be considered essential for the endolithic habit nor a characteristic of endolithic thalli, though the oil itself, which is common to the hyphae-more particularly the rhizoidal hyphae-may be an essential constituent of the thallus tissue. If one considers the position of the inflated oil cells in the types described, one finds that they occur in regions of special growth. The thallus of $V$. calciseda is one of the more rapidly growing species. It has been observed during the present investigation to oust from their positions $P$. rupestre, var. calvum, forma incrustans, and $L$. immersa, both of which are found to be without inflated cells in their thallus tissues. Fünfstiick (loc. cit.) found inflated oil cells of L. immersa $8 \mathrm{~mm}$. below the limestone surface, but in the thalli examined in the present 


\section{$55^{8}$ Fry.-Some Types of Endolithic Limestone Lichens.}

investigation $L$. immersa only penetrates to a depth of $1,100 \mu$, and no inflations, of the complicated type figured by Fünfstück, are found. Fünfstuick states that Opegrapha saxicola is one of the richest in oil cells. He also says in another connexion that $O$. saxicola and $V$. calciseda are rapidly growing forms. The rate of growth of lichen ' $X$ ' is not known. It is interesting to note, in connexion with the development of the perithecia of $V$. calciseda and the apothecia of $L$.immersa, that oil cells are prominent. It is also curious that, even in the case of $A$. calcarea, where the apothecia are in the epilithic part of the thallus, there is in the rock below an unusual formation of these cells full of oil. It may be worth mentioning as a characteristic feature of the genus that during its early development the apothecium remains immersed in the thallus tissue. In regions of growth, or any other plant activity, carbon dioxide is given off, and in regions of rapid or locally concentrated growth one would expect a proportionally increased evolution of the gas. In these endolithic lichens it is in such regions that one finds the main masses of oil cellules, and it is in these same places that the more rapid solution of the limestone goes on. It seems natural to conclude, therefore, that growth, formation of oil, evolution of carbon dioxide, and solution of the limestone are intimately related. If this is so, then one can suggest a solution of the phenomenon of limestone penetration by these lichens. Such a solution would also explain penetration of the rock by Trentepohlia and moss rhizoids.

Various theories have been advanced to explain the use of the fatty material. It was stated by Zukal (15) to be a food reserve in case of drought or extra strain on the resources of the lichen. This has been disproved by Fünfstuick's (loc. cit.) experiments on $V$. calciseda and $O$. saxicola. The researches of Beyerinck (12), Wehmer (13), and Stahel (14) all go to show that the formation of the fatty material is due to adverse conditions, such as absence of nitrogen or excess of calcium carbonate, while respiration is actively proceeding. Some of the material used in the present investigation had been kept dry and in the dark for two or four years, and it is interesting to note that the inflated cells and hyphae were full of oil at the end of those periods. As stated by Miss Lorrain Smith (8), the results obtained by the above investigators show how the fatty substance may be formed in those lichens which are deprived of nitrogen and have an excess of carbon dioxide which is not readily removed. This is clearly brought out in the present investigation, for wherever carbon dioxide evolution is at its greatest, there one finds the greatest formation of inflated oil hyphae. Furthermore, in the slower-growing species, inflated hyphae are absent, the oil being stored as small globules in the ordinary narrow hyphae. From the above considerations one can conclude with Fünfstück (loc. cit.) that the oil is a waste product formed under the special endolithic conditions.

Various theories have also been put forward by different investigators 
to explain the boring action of the fine hyphae into the limestone, but they have all been discredited. That put forward by Wallroth (16) may be instanced. He stated that the rhizoids excreted an acid fluid which dissolved the limestone, the remainder of the thallus being raised in the air. Owing to the precipitation of calcium carbonate in the intercellular spaces of the thallus, the latter was so highly charged with the carbonate that it became as hard as stone. A consideration of the results of this investigation has led the writer to form the following hypothesis to explain the boring action of these lichens. The boring action is performed by the carbon dioxide of respiration, dissolved in the water which soaks down from the surface, and is retained by capillarity in the numerous cracks and pores in the limestone. This carbonic acid acts on the rock forming the soluble bicarbonate. This solution diffuses up, between the hyphae and the walls of the cavities made by them, to the surface film of water. From the surface it may either be washed away by the next shower of rain, or, in the case of drought setting in, it may precipitate the more stable carbonate on the surface. The continual precipitation of calcium carbonate on the surface of the embedded lichen will account for the permanent granular appearance of the surface of the endolithic thallus examined. There are numerous small depressions on the flat tables of limestone, and in these rain-water tends to collect. If this water is allowed to remain for a short time, it is found to contain calcium carbonate in solution. In the cases under discussion, since there is no chance of water, already containing calcium carbonate, draining into the depression, the carbonate must be derived either from the solution of the granules of limestone on the surface of the endolithic thalli, or by diffusion into the water of the bicarbonate produced by the boring action of the endolithic lichens lining the depression, or from both these sources. The rain-water probably contains a small amount of atmospheric carbon dioxide in solution, and this, together with the carbon dioxide of respiration of the rock lichens, is sufficient to dissolve the granules of limestone deposited on the surface as described above. If the small collection of water dries up, the dissolved limestone will be reprecipitated on the thalli, but in the case of a shower of rain it will be washed down into the neighbouring crevices; since the rainfall in these regions is very high, this will frequently take place. This will also explain the removal from the apothecial pits of the undissolved particles of limestone, for the processes which go on on a large scale in the depressions are also in progress in the minute apothecial hollows.

One has already come to the conclusion that the carbon dioxide of respiration of lichens on other substrata than limestone, e.g. shale, is responsible for a considerable proportion of the decomposition of the rock in their immediate vicinity. Miss Mellor (17) also has recently published a paper proving that the carbon dioxide of lichen respiration in solution 
in the condensed water vapour of the atmosphere plays a considerable part in the decomposition of glass.

\section{SUMMARY.}

I. The investigation suggested itself during a general study of cryptogamic ecology, and this paper is confined to the examination of certain endolithic limestone lichens.

2. The method of preparation of material for study was to decalcify, with dilute hydrochloric acid, the lichen thallus as a whole, then wash it free of acid, fix, dehydrate, embed, cut serial sections, stain, and mount in the usual way.

3. The classification adopted is based on the thallus structure.

4. Endolithic lichens have a structure similar to that of sub-aerial forms.

5. The fruiting bodies originate within the rock--the deep pits being formed during development.

6. In regions of special growth numerous spherically inflated hyphae containing oil are found. In these same regions the solution of the limestone is more rapid. There is probably some relation between growth, evolution of carbon dioxide, oil formation, and solution of the limestone.

7. Inflated oil hyphae are absent in slower-growing species, but oil globules in the ordinary hyphae are common to all forms.

8. The oil is not stored food, but waste material produced under adverse conditions during the evolution of carbon dioxide; consequently there is an increased output of oil where growth is specially active.

9. It is suggested that the boring action is brought about by the carbon dioxide of respiration dissolved in water. The dilute acid attacks the rock, the soluble bicarbonate being formed. This is precipitated at the surface as the stable carbonate. The precipitation causes the granular appearance of the surface of endolithic thalli. The granules are constantly replaced by the fresh precipitation of calcium carbonate.

I am much indebted to Professor Lloyd Williams, D.Sc., University College of Wales, Aberystwyth, for his kind help and encouragement with this investigation. My thanks are due to Miss Lorrain Smith, F.L.S., Mr. D. A. Jones, M.Sc., Mr. Hebden, and Mr. Wheldon, F.L.S., for their kindness in verifying and identifying lichens, both in connexion with this and previous investigations. 


\section{BIBLIOGRAPHY.}

1. Bachmann, E. : Der Thallus der Kalkflechten. Wiss. Beil. Realsch. Plauen I.v.; Ber. Deutsch. Bot. Ges. x. 1892 .

: Der Thallus der Kalkflechten. II. Flechten mit Chroolepusgonidien. Ber. Deutsch. Bot. Ges., xxxi. I9I3.

2. Steiner, J. : Verrucaria calciseda, Petractis exanthematica, ein Beitrag zur Kenntniss des Banes und der Entwickelung der Krustenflechten. Programm K. K. Staatsobergymn. Klagenfurt, xxxi. 188I.

3. Fünfstück, M. : Die Fettabscheidung der Kalkflechten, in Fünfstück's Beitr. wiss. Bot., i, I 895 , and Nachtrag, I 896 .

: Weitere Untersuchungen über die Fettabscheidung der Kalkflechten. Bot. Untersuch., Festschrift für Schwendener, Berlin, I 899 .

4. Friederich, A. : Beiträge zur Anatomie der Silikatflechten. Fünfstiick's Beitr. wiss. Bot., v. I 906.

5. LANG, E. : Beiträge zur Anatomie der Krustenflechten. Ibid. I903.

6. ZuKaL, H. : Ueber das Vorkommen von Reservestoffbehältern bei Kalkflechten. Bot. Zeit., xliv. I886.

7. Tulasne, L. R.: Mémoire pour servir à l'histoire organographique et physiologique des Lichens. Ann. Sci. Nat., sér. 3, xvii. $185^{2}$.

8. Sмith, A. L. : Lichens. London, I92I.

9. Rosendahl, F.: Vergleichend anatomische Untersuchungen ïber den braunen Parmelien. Dissertation Münster I 907 and in Nova Acta, Abh. K. Leop.-Carol. Deutsch. Akad. Naturf., lxxxvii. 3. I907.

10. Bachmann, E.: Zur Frage des Vorkommens von ölführenden Sphaeroidzellen bei Flechten. Ber. Deutsch. Bot. Ges., xxii. I904.

11. $:$ Die Beziehungen der Kieselflechten zu ihrem Substrat. Ibid.

12. Beyerinck, M. W. : Das Assimilationsprodukt der Kohlensäure in den Chromatophoren der Diatomeen. Rec. Trav. Bot. Néerl., 1. I904.

13. Wehmer, CARL: Entstehung und physiologische Bedeutung der Oxalsäure im Stoffwechsel einiger Pilze. Bot. Zeit., xlix. 189 I.

14. Stahel, Gerold : Stickstoffbildung durch Pilze bei gleichzeitiger Ernährung mit gebundenem Stickstoff. Jahrb. wiss. Bot., xlix. I9II.

15. ZuKaL, H. : Morphologische und biologische Untersuchungen über die Flechten. Sitzungsb. K. Akad. Wiss., Math.-Naturw. Cl., Wien, civ. 1895 .

16. Wallroth, F. W.: Naturgeschichte der Flechten. Frankfurt am Main. I825-I827.

17. Mellor, Ethel: Les Lichens vitricoles et la détérioration des vitraux d'église. Revue générale de Botanique, tome xxiv, juin I922.

\section{EXPLANATION OF PLATE XXI.}

Illustrating Mr. Fry's paper on Some Types of Endolithic Limestone Lichens. $670 \mu)$.

Fig. I. Verrucaria calciseda. Vertical section of thallus and perithecium (depth in limestone,

Fig. 2. $V$. calciseda. Vertical section of black marginal region between $V$. calciseda and Placodium rupestre, var. calvum, forma incrustans.

Fig. 3. Lichen ' $\mathrm{X}$ '. Vertical section of thallus (depth in limestone, $\mathrm{I}, 000-\mathrm{I}, \mathrm{I} 00 \mu$ ).

Fig. 4. Lichen ' $\mathrm{X}$ '. Macrospore.

Fig. 5. Lichen ' $\mathrm{X}$ '. Macrospore.

Fig. 6. Lichen ' $X$ '. Macrospore.

Fig. 7. Lichen ' $\mathrm{X}$ '. Macrospore. 


\section{Fry.-Some Types of Endolithic Limestone Lichens.}

Fig. 8. Placodium mpestre, var. calvum, forma incrustans. Low power. Vertical section of thallus and apothecium (depth in limestone, $160 \mu$ ).

Fig. 9. P. rupestre, var. calvum, form incrustans. Vertical section of part of thallus.

Fig. Io. Lichen 'Y'. (Gonidia, Trentepohlia). Vertical section of thallus (depth in limestone, I $40-200 \mu$ ).

Fig. I I. Lichen ' $Y$ '. Gonidial cell from lower part of thallus.

Fig. I 2. Lichen ' $\mathrm{Y}$ '. Gonidial cell from lower part of thallus.

Fig. I3. Lichen 'Y'. Lichen spore germinating on surface of limestone and sending hyphae into the rock, which attack the gonidium. (Dotted area indicates limestone.)

Fig. 14. Aspicilia calcarea. Vertical section of thallus (width of whole thallus, 3,000 $\mu$ ). Depth in limestone, $2,800 \mu$. Width of epilithic thallus, I90-250 $\mu$. $a$. 'Transition' zone at top of limestone; $b$. Endolithic gonidial group; $c$. Small group of inflated cells; $e$. Four gonidial groups in vertical connexion.

Fig. I 5. Aspicilia calcarea. A few enlarged hyphal cells from the 'transition' zone.

Fig. I6. Aspicilia calcarea. Endolithic gonidial group enlarged. Gonidia surrounded by smail inflated cells.

Fig. I7. Aspicilia calcarea. Endolithic gonidial group enlarged. 
Arinals of Botany.

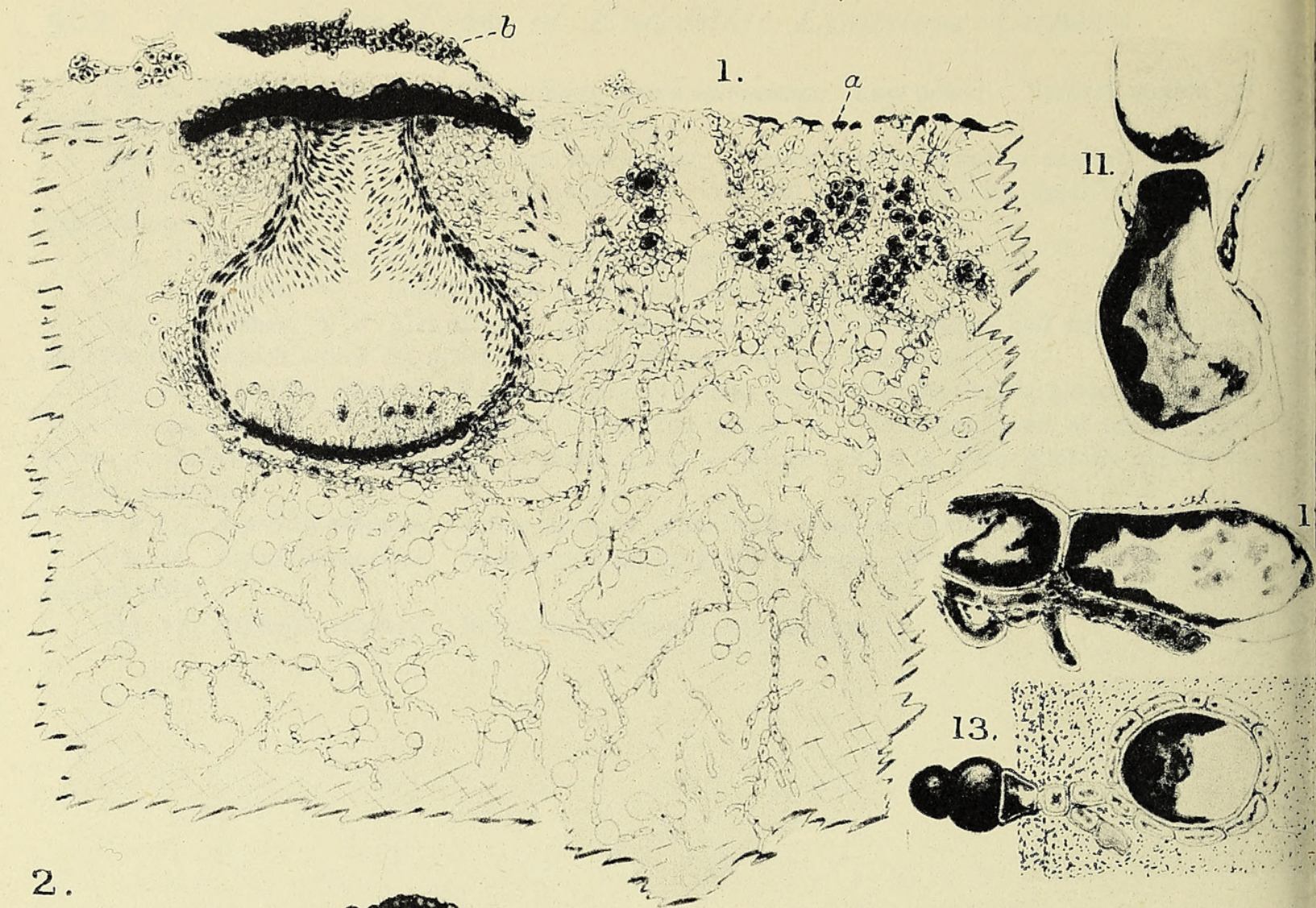

2.

4.

$-2$

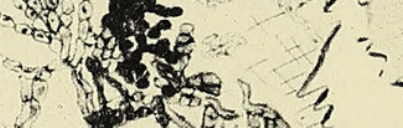
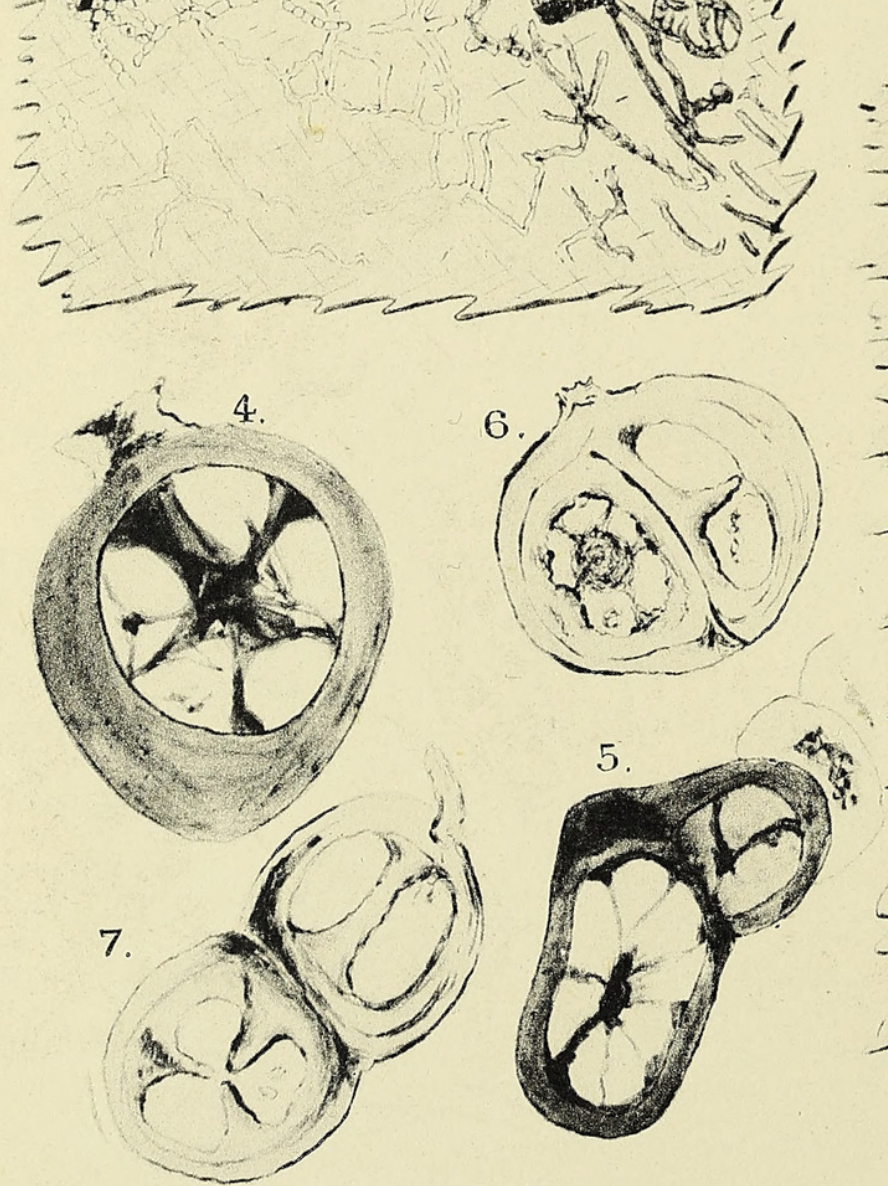

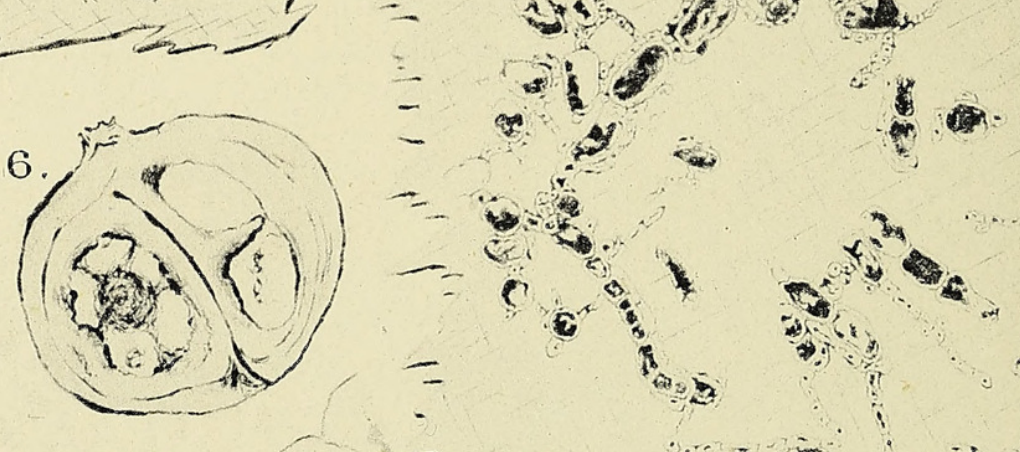

$\rightarrow \infty 8$

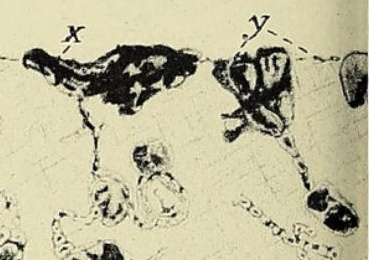

$z \quad 10$

- 3 - 0.6



(a)
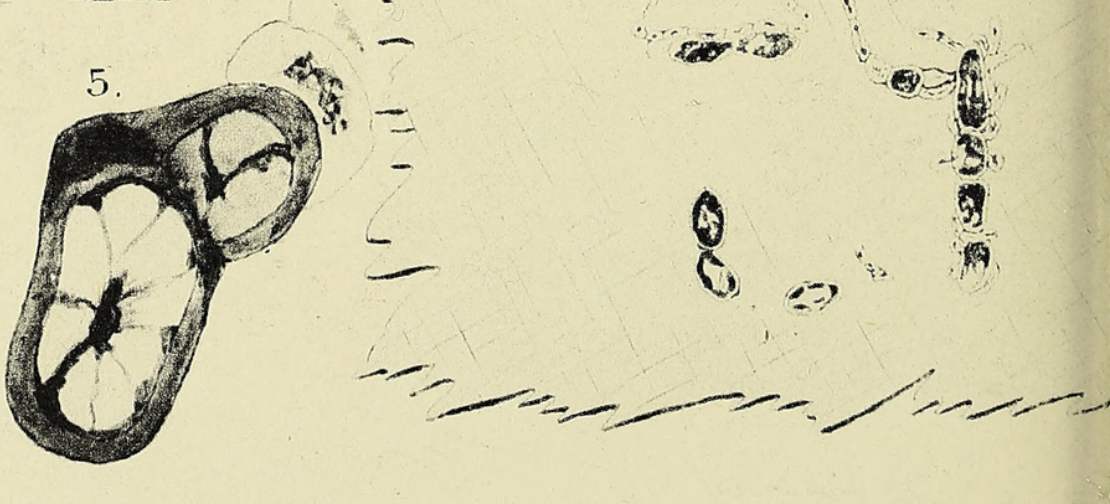

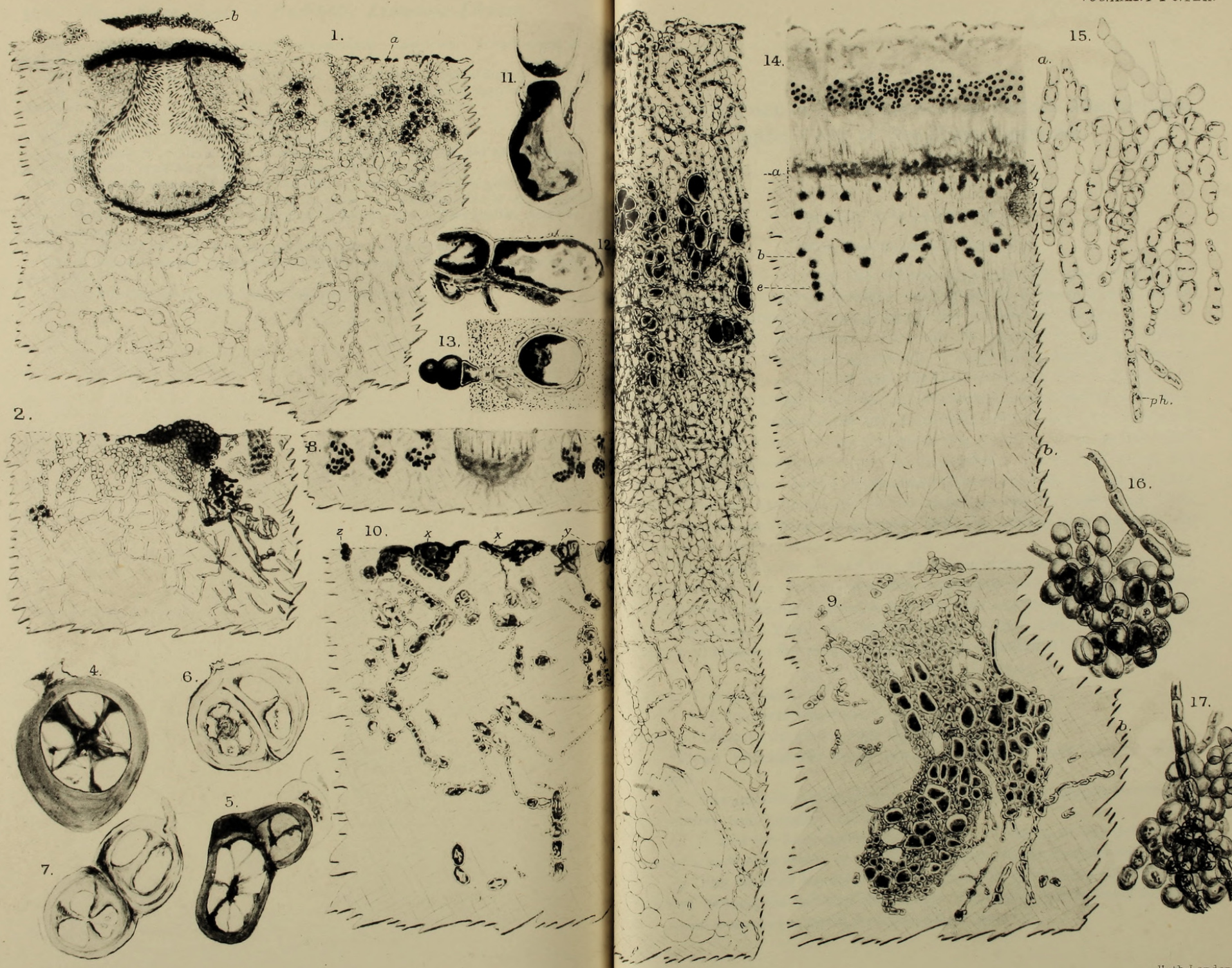

\%.

FRY - ENDOLITHIC LICHENS

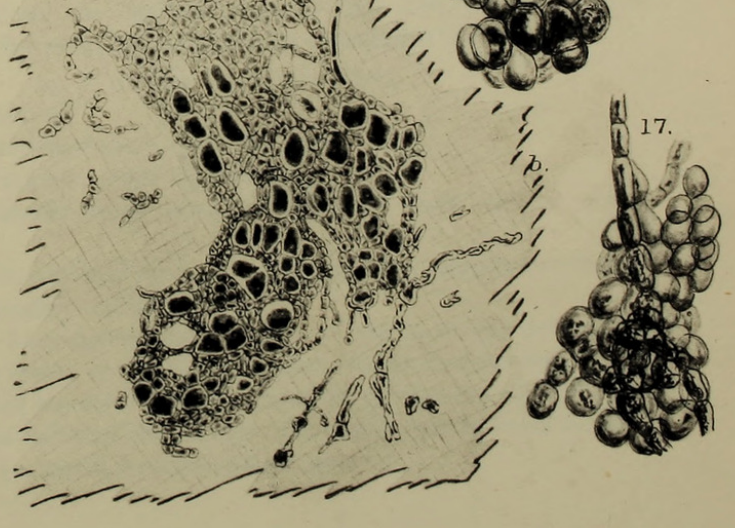




\section{$2 \mathrm{BHL}$ Biodiversity Heritage Library}

Fry, E. J. 1922. "Some types of endolithic limestone lichens." Annals of botany 36, 541-562. https://doi.org/10.1093/oxfordjournals.aob.a089823.

View This Item Online: https://www.biodiversitylibrary.org/item/234428

DOI: https://doi.org/10.1093/oxfordjournals.aob.a089823

Permalink: https://www.biodiversitylibrary.org/partpdf/319060

\section{Holding Institution}

Smithsonian Libraries

\section{Sponsored by}

Biodiversity Heritage Library

\section{Copyright \& Reuse}

Copyright Status: Not in copyright. The BHL knows of no copyright restrictions on this item.

This document was created from content at the Biodiversity Heritage Library, the world's largest open access digital library for biodiversity literature and archives. Visit BHL at https://www.biodiversitylibrary.org. 